José Florencio F. Lapeña, Jr., MA, MD

Department of Otorhinolaryngology College of Medicine, University of the Philippines Manila, Philippines

Department of Otorhinolaryngology Head and Neck Surgery

East Avenue Medical Center, Diliman

Quezon City, Philippines

\section{Publish, Don't Perish: Research and Publication for Otolaryngologists}

"Research, no matter how 'good', is incomplete, until it has been published."1

In my opinion, otolaryngology residents, fellows and consultants do not lack in research or scholarly capability. However, "the proof of the pudding is (indeed) in the eating," and scholarly societies are recognized not so much for what goes on within their hallowed halls but for what is made public outside those walls. Indeed, "publishing" means to make something public. ${ }^{2}$ And though we may not lack in research, we certainly still lag in publication.

I would therefore not be amiss in addressing the need for PSOHNS fellows, diplomates and trainees to publish, in electronic or hard-copy, in print or other media, including the social media. Because of my background, much of my reflections will deal with writing - but by no means do I mean to limit publication to that of the written word. Why write and publish?

\section{"Start Where You Are: Taking Your Place in the History of Scholarship"}

"Similar to others who write (historians and poets), scientists and those involved in research need to write ... to leave behind a documented legacy of their accomplishments." Whatever we discover or unearth in the laboratory, clinic or in the field; whether from samples, specimens, subjects, patients or participants; utilizing theoretical or applied instruments, materials and methods; simply "did not happen" unless it is documented and disseminated. In Filipino," kung hindi nakasulat, hindi nangyari." How often do we hear comments like "naisip ko na iyan," or "napresenta ko na iyan" or even "sinulat ko na iyan" at a scientific meeting where a speaker presents a study. The sad fact of the matter is that many of these colleagues may indeed have had similar thoughts, or delivered previous oral presentations, or even written reports. But because none of these had been properly published, they remain inaccessible to subsequent scholars, and are therefore neither cited nor acknowledged.

"While 'doing' the research is important, 'writing' about why and how it was done, what was found, and what it means is far more important as it serves as a permanent record of scientific work that has been completed and accepted by peers."1 And writing and publishing are an entirely different ball game from researching alone. Publication, or "making ideas public," allows "scholars (to) provide each other with the opportunity to build on each other's contributions, create dialogue (sometimes heated) with one another and join the documented and ongoing history of their field." It is by participating in this "documented and ongoing history" of whatever field we may be in, that we and our specialty society gain international recognition and become internationally competitive. 
Taking your place in the history of scholarship starts where you are, as an author. Publication involves communication between the author and his or her audience via the written article. ${ }^{3}$ Unlike public speakers or performing artists, the author's interaction with the audience is limited by the written and published work. Hence, "a successful researcher is usually a good communicator who has the ability to maximize the transmission of research findings to his or her chosen audience."1

\section{Setting the Stage: Advantages of Writing and Publication}

A few may write " for the pleasure derived from the creative activity of writing and intellectual sharing, and the desire to advance knowledge and benefit mankind" and for these individuals, "writing may act as a channel for expressing the joy of scientific discovery, and may even be regarded as a leisurely pursuit."1 $A n$ historical article on Jose Rizal ${ }^{4}$ that I researched for a year and a half before the occasion of his $150^{\text {th }}$ anniversary and another on the evolution of indirect laryngoscopy ${ }^{5}$ that I researched for two years are personal examples of these. For most everyone else, there are career, professional, institutional and practical advantages that can be gained from writing and publication. ${ }^{6}$

As far as career benefits are concerned, "getting published in prestigious, scholarly journals may have the most direct bearing on your appointment, promotion, tenure and advancement within your institution, organization and discipline."2 The "up or out" situation faced by many young to mid-career academics would have been easily avoided by publishing early. Moreover, publications are the primary basis for promotion and advancement in academe.

Professional benefits are just as important. For junior consultants and younger faculty, "having published articles in reputable international journals are a great help when applying for positions in foreign institutions, and when applying for competitive overseas fellowships."1 As editor of our specialty scholarly journal, I receive numerous urgent requests from postgraduate residents and young diplomates (unaware of the tedious editing and peer review process) to rush-publish research they undertook in training, in fulfillment of publication requirements for overseas positions or fellowships they are applying for. Had they realized this earlier, they could have been much better-prepared. For more established consultants, "gaining recognition as experts in a particular field at regional and international levels leads to invitations to lecture at scientific meetings and refresher courses, and appointments as consultants to external agencies, expert panels and advisory boards, reviewer and editorial boards."1 Much of my local and international travels are direct offshoots of previous research, lectures and publications. These generate further research and publication opportunities in turn, as track records in research and publication are considered in "applications for, extension of, and further research funding."' Closer to home, publication "increases (the) depth of knowledge in a particular subject that complements and hones clinical (practical) skills, and enables better teaching of students, clinical trainees and postgraduates."' Indeed, a true professor must have something to profess, and a well-published professor can certainly profess what he or she does more authoritatively.

Of course, the practical benefits gained from engaging in the research and publication process cannot be overlooked. The "inherent training gained during the process of manuscript preparation," the "discipline of performing a thorough literature search, collating and analyzing data and drafting and repeatedly revising the manuscript"1 during the editing and review process, provide undeniable practical benefits to the author. Researchers who have published are much better positioned to evaluate scholarly publications, having themselves experienced the writing, editing and review process. In this era of "information overload" the published researcher can more effectively evaluate and utilize available evidence.

Because of institutional benefits, it is in the best interests of our scholarly society to encourage scholarly writing, as "publication in peerreviewed journals is arguably the most important means to achieve international recognition for an individual, department, hospital, and university."1 Various international survey and ranking systems place a premium on such publication, explaining why Philippine academic institutions lag behind their counterparts in Asia and the rest of the world. It is also in the best interests of the Philippines that her clinicians, scientists, artists and scholars publish, as "the author's country, and even the region, may also derive benefit from published work, particularly if it is on a topic of major importance."1 At least in the medical field, Filipino publications have made their mark, albeit sparsely. The UP College of Medicine and National Health Sciences Journal Acta Medica Philippina is the source of material indelibly inscribed in the world medical map, and we certainly look forward to the Philippine Journal of Otolaryngology Head and Neck Surgery achieving the same.

The generous research allocation for Fellows and full support for our journal by the PSOHNS Board of Trustees are a step in the right direction, as are the annual awarding of the Outstanding ENT Specialist in Research and Editors' Pick Award for Outstanding Publication. In keeping with international practice, we should accord due public recognition to our 


\section{EDITORIAL}

excellent Reviewers and Editors at official PSOHNS functions such as Annual Conventions, if but for the recognition they reciprocally bring to the society. The American Academy of Otolaryngology Head and Neck Surgery has journal Editors and Star Reviewers wear special ribbons at their Annual Meeting, and openly campaigns for participants to thank these reviewers for their contribution.

On another note, I was elected President 2014-2016 of the Asia Pacific Association of Medical Journal Editors during the recent Joint Meeting of APAME and the Western Pacific Region Index Medicus and Index Medicus of the South East Asia Region of WHO in Ulaanbaatar, Mongolia last August $15-17,2014$. This is fortuitous as we prepare to host the APAME Convention 2015 and Joint Meeting with WPRIM and IMSEAR at the WHO Western Pacific Region Office, Sofitel Hotel and Philippine International Convention Center from August 24-26, 2015 in conjunction with FORUM 2015. The other officers are: Executive Vice President Prof. Jeong-WookSeo (Korea), Vice President for Internal Affairs Prof. Kiichiro Tsutani (Japan), Vice President for External Affairs Prof. Dai Tao (China) and Secretary-General Prof. Wilfred Peh (Singapore).

The Philippine Journal of Otolaryngology Head and Neck Surgery is now indexed in the HINARI Access to Research in Health Programme of the World Health Organization www.who.int/hinari making us readily available to a multitude of users from developing countries and increasing our accessibility tremendously. Our society and journal can be accessed via http://extranet.who.int/hinari/en/browse_publisher. php?pub=695

In addition, APAMED Central (on which the Philippine Journal of Otolaryngology Head and Neck Surgery is indexed) has been formally ratified for indexing in the worldwidescience.org database during the World Wide Science Alliance annual meeting in Tokyo last October 2014. Henceforth, all articles from Oct 19 2014, including this issue, will be searchable on this database.

Finally, I am especially thankful to our President and my friend, Howard M. Enriquez, MD and the PSOHNS Board of Trustees (especially the Scientific Committee Chair and my friend Elmo R. Lago, Jr., MD) for the support given to me, and our journal on my ninth year as Editor-inChief.

\section{REFERENCES}

1. Peh WCG, Ng KH. Effective medical writing (Pointers to getting your article published): Why Write? Singapore Med J 2008; 49(6):443.

2. Publish, Not Perish:The Art and Craft of Publishing in Scholarly Journals. University of Colorado 2006. Available from http://www.publishnotperish.org [cited May 25, 2013].

3. Clearihan L. Writing for Publication. Monash Uniiversity, Melbourne. Available from: http:// www.phcris.org.au/conference/2005/workshops/clearihan.pdf [cited May 25, 2013].

4. Lapeña JF. José Protacio Rizal (1861-1896): physician and Philippine national hero. Medicine in Stamps Series. Singapore Med J. 2011 Jun; 52(6):390-393.

5. Lapeña JF. Mirrors and Reflections: The Evolution of Indirect Laryngoscopy. Ann Saudi Med 2013 Mar-Apr; 33(2): 177-181. DOI: 10.5144/0256-4947.2013.177

6. Peh WCG. Scientific writing and publishing: its importance to radiologists. Biomed Imaging Interv J 2007;3(3):e55 doi: 10.2349/biij.3.3.e55. 